\title{
Acute human bocavirus 1 infection in child with life-threatening bilateral bronchiolitis and right-sided pneumonia: a case report
}

Inga Ziemele ${ }^{1,2^{*}}$, Man Xu ${ }^{3}$, Anda Vilmane ${ }^{4}$, Santa Rasa-Dzelzkaleja ${ }^{4}$, Lea Hedman ${ }^{3,5}$, Klaus Hedman ${ }^{3,5}$, Maria Söderlund-Venermo ${ }^{3}$, Zaiga Nora-Krukle ${ }^{4}$, Modra Murovska ${ }^{4}$ and Dace Gardovska ${ }^{1,2}$

\begin{abstract}
Background: Human bocavirus 1 is a commonly detected human parvovirus. Many studies have shown human bocavirus 1 as a pathogen in association with acute respiratory tract infections in children. However, because human bocavirus 1 persists in the upper airways for extensive time periods after acute infection, the definition and diagnostics of acute human bocavirus 1 infection is challenging. Until now, detection of human bocavirus 1 exclusively, high viral load in respiratory samples, and viremia have been associated with a clinical picture of acute respiratory illness. There are no studies showing detection of human bocavirus 1 messenger ribonucleic acid in the peripheral blood mononuclear cells as a diagnostic marker for acute lower respiratory tract infection.

Case presentation: We report the case of a 17-month-old Latvian boy who presented in intensive care unit with acute bilateral bronchiolitis, with a history of rhinorrhea and cough for 6 days and fever for the last 2 days prior to admission, followed by severe respiratory distress and tracheal intubation. Human bocavirus 1 was the only respiratory virus detected by a qualitative multiplex polymerase chain reaction panel. For the diagnosis of acute human bocavirus 1 infection, both molecular and serological approaches were used. Human bocavirus 1 deoxyribonucleic acid (DNA) was detected simultaneously in nasopharyngeal aspirate, stool, and blood, as well as in the corresponding cell-free blood plasma by qualitative and quantitative polymerase chain reaction, revealing high DNA-copy numbers in nasopharyngeal aspirate and stool. Despite a low-load viremia, human bocavirus 1 messenger ribonucleic acid was found in the peripheral blood mononuclear cells. For detection of human bocavirus 1-specific antibodies, non-competitive immunoglobulin $\mathrm{M}$ and competitive immunoglobulin $\mathrm{G}$ enzyme immunoassays were used. The plasma was positive for both human bocavirus 1-specific immunoglobulin $\mathrm{M}$ and immunoglobulin $\mathrm{G}$ antibodies.
\end{abstract}

Conclusions: The presence of human bocavirus 1 genomic DNA in blood plasma and human bocavirus 1 messenger ribonucleic acid in peripheral blood mononuclear cells together with human bocavirus 1-specific immunoglobulin $\mathrm{M}$ are markers of acute human bocavirus 1 infection that may cause life-threatening acute bronchiolitis.

Keywords: Human bocavirus 1, Lower respiratory tract infection, Acute bronchiolitis, Children

\footnotetext{
* Correspondence: inga.ziemele@gmail.com

${ }^{1}$ Children's Clinical University Hospital, Riga, Latvia

${ }^{2}$ Department of Pediatrics Rīga Stradinš University, Riga, Latvia

Full list of author information is available at the end of the article
}

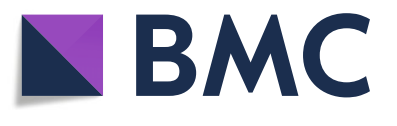

(c) The Author(s). 2019 Open Access This article is distributed under the terms of the Creative Commons Attribution 4.0 International License (http://creativecommons.org/licenses/by/4.0/), which permits unrestricted use, distribution, and reproduction in any medium, provided you give appropriate credit to the original author(s) and the source, provide a link to the Creative Commons license, and indicate if changes were made. The Creative Commons Public Domain Dedication waiver (http://creativecommons.org/publicdomain/zero/1.0/) applies to the data made available in this article, unless otherwise stated. 


\section{Background}

Acute lower respiratory tract infections (LRTIs) are responsible for significant morbidity and mortality in infants and young children worldwide. Childhood pneumonia accounts for $16 \%$ of all deaths of children under 5 years of age and $7-13 \%$ of all community cases are life-threatening and require hospitalization. The most common causes of acute LRTIs with divergent presentation are viruses. Respiratory syncytial virus (RSV) is the most common viral cause of pneumonia in young children $[1,2]$.

Human bocavirus 1 (HBoV1), the second human pathogenic virus in the family Parvoviridae, was discovered in 2005 in nasopharyngeal aspirates (NPAs) of children with acute respiratory tract infection (ARTI) [3]. Since then, HBoV1-associated ARTIs have been reported worldwide [4].

On the one hand, there are studies showing evidence of HBoV1 as a pathogen in association with LRTIs, mainly in children up to 3 years of age [5-10]. On the other hand, HBoV1 has also been found in asymptomatic children [11-14]. These states of affairs at first may seem contradictory; however, $\mathrm{HBoV} 1$ has been shown to remain in the nasopharynx for several weeks and even months, thereby causing clinically false polymerase chain reaction (PCR) diagnoses. Moreover, life-threatening and even fatal HBoV1 infections have been reported [15-19]. The definition and diagnosis of acute HBoV1 respiratory tract infection is challenging. Detection of HBoV1 deoxyribonucleic acid (DNA) in blood, messenger ribonucleic acid (mRNA), and viral load assessment in respiratory samples and serology have been recommended as the markers to diagnose active HBoV1 infection $[6,7$, 20, 21]. According to the best of our knowledge, there are no studies up to now showing detection of HBoV1 mRNA in the peripheral blood mononuclear cells (PBMCs) as a diagnostic marker for acute HBoV1 infection.

In this study, we report an acute HBoV1 infection in an otherwise healthy child with life-threatening acute bilateral bronchiolitis and right-side pneumonia with detected HBoV1-specific immunoglobulin (Ig) $\mathrm{M}$ and DNA in cell-free blood plasma as well as HBoV1 mRNA in PBMC.

\section{Case report}

A 17-month-old Latvian boy was admitted to the Children's Clinical University Hospital of Riga, Latvia, on the seventh day of illness in January 2015. He presented with a history of rhinorrhea and cough for 6 days and fever (axillar temperature $39.0^{\circ} \mathrm{C}$ ) for the last 2 days prior to admission. Due to severe respiratory distress, he was immediately transferred from the regional hospital to our intensive care unit.
On admission, his respiratory rate was 44 breaths/minute (reference $20-30$ ), heart rate 146 beats/minute (reference 80-130), oxygen saturation 99\% (with an oxygen flow of 5 liters/minute via face mask), and axillary temperature $38.7^{\circ} \mathrm{C}$. Auscultation of his lungs revealed bilateral wheezing and crepitation with severe intercostal and subcostal recessions. The other organ systems were without pathology. Due to the severe respiratory distress, tracheal intubation was performed.

The child had been born full term as the seventh in the family. He had no known underlying illness, history of previous hospitalizations, or severe acute illnesses. He had been fully immunized according to the national immunization scheme.

On admission, his white blood cell (WBC) count was $30.6 \times 10^{3} / \mu \mathrm{L}$ with $66.9 \%$ of granulocytes (in absolute numbers $20.6 \times 10^{3} / \mu \mathrm{L}$ ), hemoglobin $12.4 \mathrm{~g} / \mathrm{dL}$, and platelet count $321 \times 10^{3} / \mu \mathrm{L}$. His C-reactive protein (CRP) was $5.09 \mathrm{mg} / \mathrm{L}$. A chest radiograph showed infiltration of the upper lobe of his right lung (Fig. 1).

At the time of admission, a nasopharyngeal swab (NPS) tested negative by direct immunofluorescence (IMAGEN $^{\text {su }}$ OXOID, UK) for antigens of RSV, influenza virus $A$ and $B$, parainfluenza virus types $1-3$, and adenovirus. Bacterial blood cultures were negative. NPA, blood, and stool samples were collected for HBoV1 molecular diagnostics and serology.

NPA tested by qualitative multiplex PCR (Seegene Respiratory Panel, South Korea) was negative for: influenza virus $A$ and $B$; RSV A and B; flu A types $H 1, H 1 p d m 09$, and $\mathrm{H} 3$; adenovirus; enterovirus; parainfluenza virus

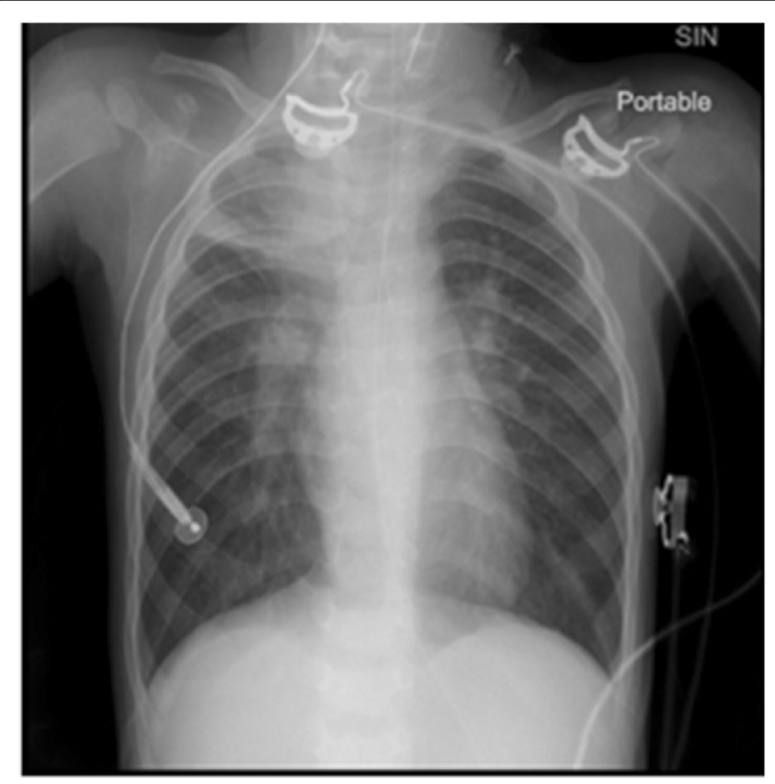

Fig. 1 Chest radiograph (anteroposterior view) of the patient on the first day of hospitalization, showing upper right-side pneumonia 
types 1-4; metapneumovirus; rhinovirus; and coronavirus types NL63, 229E, and OC43. However, the NPA tested by qualitative multiplex PCR was positive for HBoV1. NPA, whole blood with corresponding cell-free blood plasma, and stool samples underwent qualitative PCR for HBoV1 NS1 DNA, as described [20]. An HBoV1-containing plasmid was used as a positive control in PCR. All these samples were HBoV1 DNA positive. Upon re-examination by quantitative PCR (qPCR) (Human bocavirus genomes, Standard kit, Genesig, Primerdesign Ltd., UK), the copy numbers in NPA and stool were high, $5.7 \times 10^{5}$ per $\mu \mathrm{g}$ DNA in NPA and $1.4 \times 10^{8}$ per $\mu \mathrm{g}$ DNA in stool. The viral load in blood was 21 copies/ $\mu \mathrm{g}$ DNA, but in cell-free blood plasma the viral load was under detection level.

To prove that the HBoV1 infection was actively ongoing, HBoV1 transcription in PBMCs was applied. Total ribonucleic acid (RNA) was extracted from PBMCs using TRI Reagent ${ }^{\oplus}$ solution according to the manufacturer's instructions (Thermo Fisher Scientific, USA). The extracted RNA was quantified spectrophotometrically and analyzed by electrophoresis in a 1\% agarose gel. RNA was treated with DNase (TURBO DNAfree $^{\mathrm{mm}}$ Kit, Thermo Fisher Scientific, USA) before the synthesis of complementary DNA (cDNA) by the reverse transcriptase (RT) using RevertAid ${ }^{\mathrm{TM}}$ First Strand cDNA Synthesis Kit (Thermo Fisher Scientific, USA). The $\beta$ actin gene sequence was detected by PCR to assess the quality of synthesized cDNA (Fig. 2).

HBoV1-specific cDNA was detected by PCR targeting the HBoV1 NS1 gene as described by Sloots et al., in

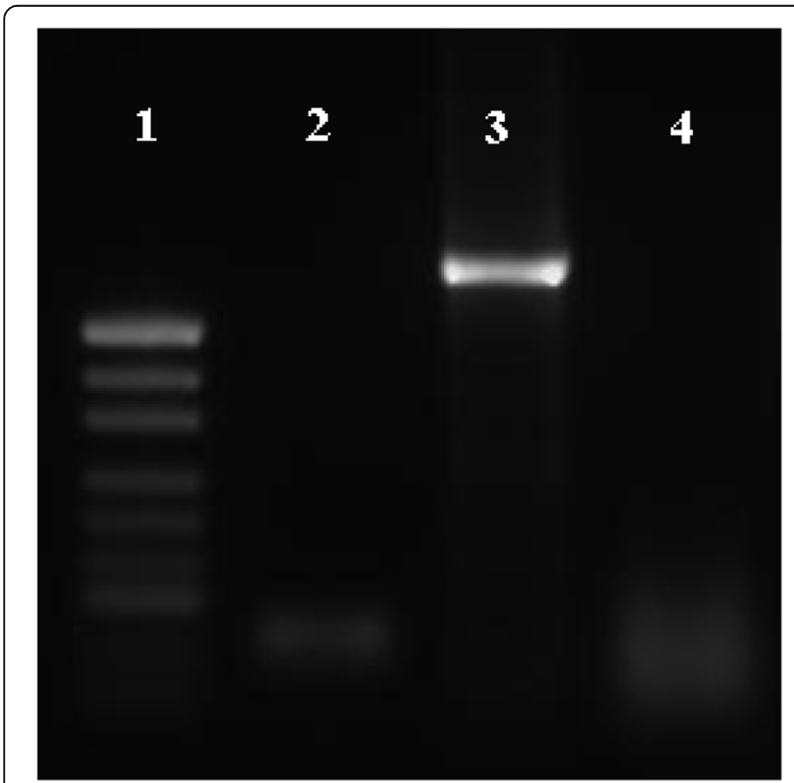

Fig. 2 Electrophoretic visualization of amplification products in a $1 \%$ agarose gel after polymerase chain reaction targeting $\beta$-actin gene sequence
2006, followed by electrophoretic visualization of the amplification products in a $1.7 \%$ agarose gel (Fig. 3) [22]. The same DNase-treated RNA sample but without the RT step, served as a negative control in both the $\beta$-globin and HBoV1 PCRs to make sure that there was no contamination with DNA.

Biotinylated virus-like particles (VLPs) of the recombinant major capsid protein VP3 were used as antigen in enzyme immunoassays (EIAs) for detection of HBoV1specific immunoglobulin $M$ (IgM) and immunoglobulin $G$ (IgG) in our patient's plasma sample [23, 24]. For removal of possible cross-reacting heterologous human bocavirus 2 (HBoV2) and human bocavirus 3 (HBoV3) IgG, non-biotinylated VLPs in competition assays were used as described [24]. Our patient's plasma sample was positive for both HBoV1-specific IgM and IgG antibodies.

Because of the right lung upper lobe infiltration and increased WBC initially, the child was treated with intravenously administered ceftriaxone $350 \mathrm{mg}$ twice a day for 7 days and per-oral oseltamivir $30 \mathrm{mg}$ twice a day (due to influenza season). Oseltamivir was discontinued after 3 days due to the negative influenza virus $A$ and $B$ antigen findings. Extubated on day 3, our patient was brought to the Department of Paediatrics, where intravenously administered ceftriaxone was continued, inhalations via nebulizer with salbutamol and budesonide were begun and pulmonary rehabilitation started. During the next 10 days, the child's general condition improved, his body temperature was normal, lung sounds were without the pathology, and no additional oxygen was needed. During the hospitalization, poor weight gain was observed for our patient; therefore, additional diagnostic tests were done and his hospitalization length increased. On day 17 of hospitalization, he developed a new episode of fever for 2 days. The second NPS tested negative for RSV, and influenza virus A and B; however, self-limiting viral upper respiratory tract infection was suspected and he was treated with intravenously administered rehydration and ibuprofen $70 \mathrm{mg}$ for these 2 days. Due to the very low socioeconomic status of the family, he was kept in the hospital mainly for observation, although his general condition was good. On day 30 he developed a new episode of fever, cough, and wheezing lasting 6 days. In this episode, LRTI was diagnosed based on the clinical symptoms and he was treated with nebulized salbutamol and budesonide.

After 46 days of hospitalization he recovered completely from HBoV1-associated acute bilateral bronchiolitis with right-side pneumonia and a subsequent hospital-acquired upper and LRTI and was discharged.

\section{Discussion}

HBoV1 is frequently found in respiratory tract samples collected from hospitalized children with a peak age up to 24 months [24-26]. By PCR it appears as the third 


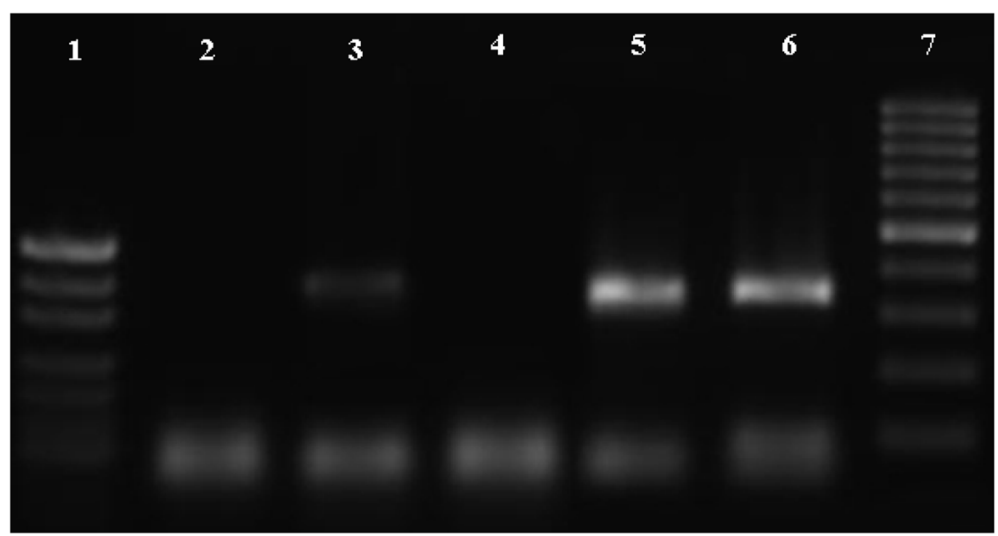

Fig. 3 Electrophoretic visualization of amplification products in a 1.7\% agarose gel after polymerase chain reaction targeting human bocavirus 1 NS1 gene. Legend 1: 1. pUC19 DNA/Mspl (Hpall) marker; 2. negative control (molecular biology grade $\mathrm{H}_{2} \mathrm{O}$ ); 3. complementary DNA sample synthesized from DNase treated ribonucleic acid; 4. DNase treated ribonucleic acid sample without reverse transcriptase step. Legend 2: 1. pUC19 DNA/Mspl (Hpall) marker; 2. DNase treated ribonucleic acid sample without reverse transcriptase step; 3. complementary DNA sample synthesized from DNase treated ribonucleic acid; 4. negative control (molecular biology grade $\mathrm{H}_{2} \mathrm{O}$ ); 5., 6. positive control (human bocavirus 1 plasmid); 7. GeneRuler 100 bp DNA Ladder

most common pathogen next to RSV and rhinovirus in young children presenting with acute bronchiolitis and wheezing [4, 27, 28]. Furthermore, serological studies have revealed that HBoV1 acute infections occur most often in early childhood, with HBoV1 IgG seroconverting at a median age of 1.9 years and reaching a seroprevalence of $80 \%$ by 6 years of age [24]. Several clinical cases have shown severe or even life-threatening respiratory tract diseases due to HBoV1 infection in children $[10,15-19,29]$. However, it should be kept in mind that, due to HBoV1 long-term persistence in the upper airways, the virus is frequently co-detected with other respiratory pathogens. The diagnosis should therefore not be based only on qualitative PCR for HBoV1 DNA in respiratory samples $[6,20,30]$. Detection of HBoV1 DNA in blood, mRNA, and viral load assessment in airway samples and serology have been recommended as better tools for diagnostics to separate active HBoV1 infection from asymptomatic virus shedding $[6,7,20,21]$.

In this report, we present a case of a 17-month-old boy with typical symptoms of acute bilateral bronchiolitis: initially rhinorrhea and cough followed by difficulty in breathing and typical findings in auscultation, including wheezing and crepitation. Fever occurred for 2 days before hospitalization and his WBC was high with absolute granulocytosis. Because the latter findings pointed to complications, chest radiography was performed and right-sided pneumonia confirmed. The onset of the clinical course and normal range CRP value, were compatible with a viral LRTI.

NPA tested by multiplex PCR was positive only for HBoV1 DNA, while 18 other respiratory viruses, including those which often cause severe bronchiolitis in this age group (RSV, rhinovirus, and human metapneumovirus), were negative. It was not surprising that HBoV1 DNA was simultaneously found by PCR in all samples including stool. Viral passage through the gastrointestinal tract due to swallowing of respiratory secretions in patients with ARTIs has been suggested [9]. By qPCR, a high viral load was detected in NPA and stool. Detection of HBoV1 exclusively, high HBoV1 DNA load in respiratory samples, and viremia are associated with a clinical picture of acute LRTI $[6,7]$. However, in some other cases the viral DNA has remained detectable in blood for a prolonged time $[15,16]$. In our patient, HBoV1 PCR was also positive in cell-free blood plasma, indicating that the virus was freed from the cells and that he had HBoV1 viremia. Diagnosis of acute HBoV1 infection is shown also by the presence of circulating HBoV1-specific IgM. Moreover, to verify that the current illness was in fact caused by acute HBoV1 infection, we looked for and found HBoV1 mRNA in PBMCs, verifying RNA transcription. To the best of our knowledge this is the first time HBoV1 mRNA has been detected in PBMCs, suggesting active replication in PBMCs. Existing data support that the detection of HBoV1 mRNA, at least in NPA, is more accurate than that of HBoV1 DNA, in the diagnosis of active infection [21, 31].

\section{Conclusions}

HBoV1 infection may cause life-threatening acute bronchiolitis, as this pediatric case demonstrates. The diagnosis of acute HBoV1 infection was proved by the presence of HBoV1-specific IgM and DNA in cell-free blood plasma as well as HBoV1 mRNA in PBMCs, whereas no other viruses or bacteria were found by PCR and culture, respectively. 


\section{Abbreviations}

ARTI: Acute respiratory tract infection; CDNA: Complementary DNA; CRP: C-reactive protein; ElA: Enzyme immunoassay; HBoV1: Human bocavirus 1; HBoV2: Human bocavirus 2; HBoV3: Human bocavirus 3; Ig: Immunoglobulin; LRTI: Lower respiratory tract infection; mRNA: Messenger ribonucleic acid; NPA: Nasopharyngeal aspirate; NPS: Nasopharyngeal swab; PBMCs: Peripheral blood mononuclear cells; PCR: Polymerase chain reaction; qPCR: Quantitative polymerase chain reaction; RNA: Ribonucleic acid; RSV: Respiratory syncytial virus; RT: Reverse transcriptase; VLPs: Virus-like particles; WBC: White blood cell

\section{Acknowledgements}

The authors thank the child's legal guardian for allowing publication of the data and Professor Hsin-Fu Liu, Department of Medical Research, Mackay Memorial Hospital, Taipei, Taiwan for gifting a HBoV1-containing plasmid.

\section{Authors' contributions}

IZ collected clinical samples, analyzed and interpreted data, and wrote the manuscript. MX and LH performed serology. AV and SR performed virus detection procedures and interpreted data. $\mathrm{KH}$ revised the manuscript. MSV contributed in serology planning, interpreted data, and revised the manuscript. ZNK contributed to concept and design of the study and revised the manuscript. MM and DG contributed in study planning and assisted in critical writing. All authors read and approved the final manuscript.

\section{Funding}

This study was supported in part by the Rĩga Stradinš University research project "Epidemiology, pathogenicity of human bocavirus (HBoV) types and their possible connection to lower respiratory tract diseases and acute gastroenteritis in children", RSU ZP 17/2013, National Research Program "BIOMEDICINE" project Nr. 5.6.2, the Sigrid Jusélius Foundation, and the Life and Health Medical Grant Association.

\section{Availability of data and materials}

Data available by request to: inga.ziemele@gmail.com.

\section{Ethics approval and consent to participate}

The present study protocol was approved by the Ethics Committee of the Rīga Stradinš̌ University on May 30, 2013 (permission code: 25/30.05.2013.)

\section{Consent for publication}

Written informed consent was obtained from the patient's legal guardian for publication of this case report and any accompanying images. A copy of the written consent is available for review by the Editor-in-Chief of this journal.

\section{Competing interests}

The authors declare that they have no competing interests.

\section{Author details}

${ }^{1}$ Children's Clinical University Hospital, Riga, Latvia. ${ }^{2}$ Department of Pediatrics Rīga Stradinš University, Riga, Latvia. ${ }^{3}$ Department of Virology, University of Helsinki, Helsinki, Finland. ${ }^{4}$ Institute of Microbiology and Virology, Rīga Stradinş̌ University Riga, Riga, Latvia. ${ }^{5}$ Helsinki University Hospital Laboratory Service, Helsinki, Finland.

\section{Received: 25 January 2018 Accepted: 8 August 2019}

Published online: 14 September 2019

\section{References}

1. Rudan I, Boschi-Pinto C, Biloglav Z, Mulholland Z, Campbell H. Epidemiology and etiology of childhood pneumonia. Bull World Health Organ. 2008; 86(Suppl 5):408-16.

2. World Health Organization: Media centre. Fact sheets: Pneumonia. 2016. http://www.who.int/mediacentre/factsheets/fs331/en/.

3. Allander T, Tammi MT, Eriksson M, Bjerkner A, Tiveljung-Lindell A, Andersson B. Cloning of human parvovirus by molecular screening of respiratory tract samples. Proc Natl Acad Sci U S A. 2005;102(Suppl 36):12891-6.

4. Qui J, Söderlund-Venermo M, Young NS. Human Parvoviruses. Clin Microbiol Rev. 2017;30(Suppl 1):43-113.
5. Allander T, Jartti T, Gupta S, Neisters HGM, Lehtinen P, Osterback R, Vuorinen T, Waris M, Bjerknen A, Tiveljung-Lindell A, van der Hoogen BG, Hyypiä T, Russkanen O. Human bocavirus and acute wheezing in children. Clin Infect Dis. 2007:44(Suppl 7):904-10.

6. Söderlund-Venermo M, Lahtinen A, Jartti T, Hedman L, Kemppainen K, Lehtinen P, Allander T, Ruuskanen O, Hedman K. Clinical assessment and improved diagnosis of bocavirus-induced wheezing in children, Finland. Emerg Infect Dis. 2009;15(Suppl 9):1423-30.

7. Christensen A, Nordbø SA, Kroksta S, Rognlien AG, Døllner H. Human bocavirus in children: mono-detection, high viral load and viraemia are associated with respiratory tract infection. Clin Virol J. 2010;49(Suppl 3): 158-62.

8. Don M, Söderlund-Venermo M, Valent F, Lahtinen A, Hedman L, Canciani M, Hedman K, Korppi M. Serologically verified human bocavirus pneumonia in children. Pediatr Pulmonol. 2010;45(Suppl 2):120-6.

9. Paloniemi M, Lappalainen S, Salminen M, Kätkä M, Kantola K, Hedman L, Hedman K, Söderlund-Venermo M, Vesikari T. Human bocavirus are commonly found in stool of hospitalized children without causal association to acute gastroenteritis. Eur J Pediatr. 2014;173(Suppl 8):1051-7.

10. Moesker FM, van Kamper JJ, van der Eijk AA, van Rossum AM, de Hoog M, Schutten M, Smits SL, Bodewes R, Osterhaus AD, Fraaij PL. Human bocavirus infection as a cause of severe acute respiratory tract infection in children. Clin Microbiol Infect. 2015;21(Suppl 10):964.

11. von Linstow ML, Høgh M, Høgh B. Clinical and epidemiologic characteristics of human bocavirus in Danish infants. Pediatr Infect Dis J. 2008;27(Suppl 10):897-902.

12. Blessing K, Neske F, Herre U, Kreth HW, Weissbrich B. Prolonged detection of human bocavirus DNA in nasopharyngeal aspirates of children with respiratory tract disease. Pediatr Infect Dis J. 2009;28(Suppl 11):1018-9.

13. Martin ET, Fairchok MP, Kuypers J, Margaret A, Zerr DM, Wald A, Englund JA. Frequent and Prolonged Shedding of Bocavirus in Young Children Attending Daycare. J Infect Dis. 2010;201(Suppl 11):1625-32.

14. Martin ET, Kuypers J, McRoberts JP, Englund JA, Zerr DM. Human Bocavirus 1 Primary Infection and Shedding in Infants. J Infect Dis. 2015;212(Suppl 4):516-24.

15. Ursic T, Steyer A, Kopriva S, Kalan G, Kriver U, Petrovec M. Human bocavirus as the cause of a life-threatening infection. J Clin Microbiol. 2011;49(Suppl 3):1179-81.

16. Körner RW, Söderlund-Venermo M, van Koningsbruggen-Rietschel S, Kaiser R, Malecki M, Schildgen O. Severe Human Bocavirus Infection, Germany. Emerg Infect Dis. 2011;17(Suppl 12):2303-5.

17. Edner N, Castillo-Rodas P, Falk L, Hedman K, Söderlund-Venermo M, Allander T. Life-threatening respiratory tract disease with human bocavirus-1 infection in a 4-year-old child. J Clin Microbiol. 2012;50(Suppl 2):531-2.

18. Ursic T, Krivec U, Kalan G, Petrovec M. Fatal human bocavirus infection in an 18-month-old child with chronic lung disease of prematurity. Pediatr Infect Dis J. 2015;34(Suppl 1):111-2.

19. Eskola V, Xu M, Söderlund-Venermo M. Severe Lower Respiratory Tract Infection Caused by Human Bocavirus 1 in an Infant. Pediatr Infect Dis J. 2017;36(Suppl 11):1107-8.

20. Broccolo F, Falcone V, Esposito S, Toniolo A. Human bocaviruses: Possible etiologic role in respiratory infection. J Clin Virol. 2015;72:75-81.

21. Xu M, Arku B, Jartti T, Koskinen J, Peltola V, Hedman K, SöderlundVenermo M. Comparative Diagnosis of Human Bocavirus 1 Respiratory Infection With Messenger RNA Reverse-Transcription Polymerase Chain Reaction (PRC), DNA Quantitative PCR, and Serology. J Infect Dis. 2017; 215(Suppl 10):1551-7.

22. Sloots TP, McErlean P, Speicher DJ, Arden KE, Nissen MD, Mackay IM. Evidence of human coronavirus HUK1 and human bocavirus in Australian children. J Clin Virol J. 2006;35(Suppl 1):99-102.

23. Kantola K, Hedman L, Allander T, Jartti T, Lehtinen P, Ruuskanen O, Hedman K, Söderlund-Venermo M. Serodiagnosis of human bocavirus infection. Clin Infect Dis. 2008;46(Suppl 4):540-6.

24. Kantola K, Hedman L, Tanner L, Simell V, Makinen M, Partanen J, Sadeghi M, Veijola R, Knip M, llonen J, Hyoty H, Toppari J, Simell O, Hedman K, Söderlund-Venermo M. B-cell Responses of Human Bocavirus 1-4: New Insights from a Childhood Follow-Up Study. Plos ONE. 2015;10(Suppl 9):1-12.

25. Jartti T, Hedman K, Jartti L, Ruuskanen O, Allander T, Söderlund-Venermo M. Human bocavirus - the first 5 years. Rev Med Virol. 2012;22(Suppl 1):46-64.

26. Nora-Krūkle Z, Rasa S, Vilmane A, Grāvelsina S, Kālis M, Ziemele I, Naciute M, Petraitiene S, Mieliauskaite D, Klimantavicience M, Girkontaite I, Liu HF, Lin 
JH, Lin YC, Chan HC, Gardovska D, Murovska M. Presence of human bocavirus 1 in hospitalized children with acute respiratory tract infections in Latvia and Lithuania. Proc Latv Acad Sci. 2016;70(Suppl 4):198-204.

27. Jacques J, Moret H, Renois F, Leveque N, Motte J, Andreoletti L. Human bocavirus quantitative DNA detection in French children hospitalized for acute bronchiolitis. J Clin Virol. 2008:43(Suppl 2):142-7.

28. Calvo C, Pozo F, García-García ML, Sanchez M, Lopez-Valero M, PérezBreña P, Casas I. Detection of new respiratory viruses in hospitalized infants with bronchiolitis: a three-year prospective study. Acta Paediatr. 2010;99(Suppl 6):883-7.

29. Jula A, Waris M, Kantole K, Peltola V, Söderlund-Venermo M, Hedman K, Ruuskanen O. Primary and secondary human bocavirus 1 infections in a family, Finland. Emerg Infect Dis. 2013;19(Suppl 8):1328-31.

30. Schildgen O, Müller A, Allander T, Mackey IM, Völz S, Kupfer B, et al. Human Bocavirus: passenger or pathogen in acute respiratory tract infections? Clin Microbiol Rev. 2008;21(Suppl 2):291-304.

31. Christensen A, Døllner H, Skanke LH, Krokstad S, Moe N, Nordbø SV. Detection of spliced mRNA from human bocavirus 1 in clinical samples from children with respiratory tract infections. Emerg Infect Dis. 2013; 4(Suppl 4):574-80.

\section{Publisher's Note}

Springer Nature remains neutral with regard to jurisdictional claims in published maps and institutional affiliations.

Ready to submit your research? Choose BMC and benefit from:

- fast, convenient online submission

- thorough peer review by experienced researchers in your field

- rapid publication on acceptance

- support for research data, including large and complex data types

- gold Open Access which fosters wider collaboration and increased citations

- maximum visibility for your research: over $100 \mathrm{M}$ website views per year

At BMC, research is always in progress.

Learn more biomedcentral.com/submissions 